\title{
RESPONSE OF GARLIC PLANTS TO NITROGEN AND SULPHUR FERTILIZATION
}

\author{
Magda A. Ewais, Sahar M. Zakaria and Amal H. El-Guibali \\ Soils, Water and Environ. Res., Inst., Agric. Res. Center, Giza, Egypt
}

Received: Apr. 24,2016

Accepted : May. 23,2016

\begin{abstract}
Garlic (Allium sativum L.) is an important vegetable crop grown in the world. It is valued for its distinctive pungent flavor and is an essential ingredient of the cuisine in many regions of the world. Hence, the present studies were undertaken in a field experiments were conducted at Agricultural Research Station El-kasasin, Ismailia Governorate, Egypt, $\left(30^{\circ} 33^{\circ}\right.$ "31 N-30 56"7 ' E, elev. $15.8 \mathrm{~m}$ ) during two seasons of 2013/2014 and 2014/2015 to evaluate growth, yield and its components, as well as chemical constituents in cloves and bulb storability of garlic (Allium sativum L.) cv. Sids-40 under three levels of nitrogen $(90,120 \mathrm{and} 150 \mathrm{~kg} \mathrm{~N} / \mathrm{fed}$ ) and four levels of elemental sulphur $\left(0,50,100\right.$ and $\left.150 \mathrm{~kg} \mathrm{~S} \mathrm{fed}^{-1}\right)$. The experiment was laid out in split plot design with three replications assigning nitrogen levels in the main plots and sulphur levels in sub-plots. The results of this study revealed that application of nitrogen and sulpher and their combinations had significant effects on most of the studied characters. The maximum plant height $(80.91 \mathrm{~cm})$, leaf number $(11.96)$, bulb diameter $(6.40 \mathrm{~cm})$, and number of cloves per bulb (21.33) and bulb yield (8980 $\left.\mathrm{kg} \mathrm{fed}^{-1}\right)$ were observed with $\mathbf{N}_{150} \boldsymbol{S}_{150}$ treatment. While the minimum plant height $(52.64 \mathrm{~cm})$, leaf number $(7.91)$, weight of bulb $(58.40 \mathrm{~g})$ and projected yield $\left(6620 \mathrm{~kg} \mathrm{fed}^{-1}\right)$ were observed under $\boldsymbol{N}_{g o} \boldsymbol{S}_{0}$ treatment. $S$ at $150 \mathrm{~kg} \mathrm{fed}^{-1}$ and nitrogen at 90 $\mathrm{kg} / \mathrm{fed}$ recorded the minimum physiological loss in weight (\%) for garlic during the storage period (6 monthes). However increasing nitrogen and decreasing sulphur level had adverse effect on storability of bulbs. Sulphur fertilization increased the Allicin concentration from $13.87 \mathrm{mg} \mathrm{g}^{-1}$ in the control treatment to $26.59 \mathrm{mg} \mathrm{g}^{-1}$ dry weight at $150 \mathrm{~kg} \mathrm{~S}^{\mathrm{fed}}{ }^{-1}$ after 2 weeks of storage period. Allicin decreased gradually in the garlic cloves during the storage period (12 weeks).
\end{abstract}

Key words: Allium sativum, Allicin, Bulb contents, Garlic, Nitrogen fertilization, Storage life, Sulphur

\section{INTRODUCTION}

Garlic (Allium sativum L.) occupies a prominent position among human foods, not only as a condiment, but also due to its therapeutic properties, attributed to the presence of bioactive compounds (Tepe et al. 2005). Garlic is a bulb from the Liliacerae family and is widely consumed all over the world. Its beneficial properties have been recognized for over 5000 years. It is indicated as an adjuvant agent in the therapy for prevention of various chronic infirmities such as heart diseases, infections, and atherosclerosis. Most of garlic's health benefits have been attributed to the antioxidant activity of organosulfurous compounds, predominantly allicin (Queiroz et al. 2009). Garlic is the food with the highest number of organosulfurous compounds. Thirty-three of these compounds have been identified, and the biological activity of several is known. On average, $1 \mathrm{~g}$ of fresh garlic contains 11 to 35 $\mathrm{mg}$ of total organosulfurous compounds, representing a level approximately four times greater (per gram of fresh weight) than that of other sources such as onions, broccoli, cauliflower, turnip, cabbage and other crucifers (Holub et al. 2002). 
Nitrogen is an essential element for plant growth and maintenance, since it is considered as key nutrients in crops production. Many researchers studied the effect of different levels of $\mathrm{N}$ fertilizers on growth, nutrients uptake and yield of garlic to find out the economic $\mathrm{N}$ fertilizers level to produce the highest garlic productivity. Applied $\mathrm{N}$ significantly increased vegetative growth and yield parameters of garlic (Naruka et al. 2005). Nitrogen is a fertilizer in a balance and rational way to keep high and stable yield and is an important component of proteins, enzymes and vitamins in plant as well as a central part of the chlorophyll, the essential photosynthetic molecule.

Sulphur is essential for synthesis of proteins, vitamins and sulphur containing essential amino acids (cysteine, cystine and methionine) and is also associated with nitrogen metabolism. Sulphur has been recognized as an important nutrient for higher yield, quality as well as nutrient uptake of garlic. Sulphur not only increases the bulb yield but also improves its quality especially pungency and flavor. Sulphur containing compounds are not only of importance for nutritive value or flavors but also for resistance against pests and diseases (Ullah et al. 2008). Severe sulphur deficiency during bulb development has detrimental effects on yield and quality of garlic (Ajay and Singh, 1994). Insufficiency of sulphur is known to hamper $\mathrm{N}$ metabolism and synthesis of sulphur containing amino acids and thus exerts adverse effects on both yield and quality of the crop.

The present investigation was undertaken to find out the effect of nitrogen and sulphur on growth, yield, quality, nutrients uptake and storability of garlic.

\section{MATERIALS AND METHODS}

Two field experiments were carried out in El-kasasin, Farm (30 $33^{\prime \prime} 31$ ' N- $30^{\circ}$ 56"7 ' $\mathrm{E}$, elev. $15.8 \mathrm{~m})$, Ismailia Governorate,
Egypt during two growing seasons of 2013 / 2014 and 2014/2015, to study the effects of nitrogen and sulphur application on growth, yield and its components, as well as chemical constituents of cloves and bulb storability of garlic cv. (Sids-40) grown in a sandy loam soil. The experiment with three levels of nitrogen $(90,120$ and $150 \mathrm{~kg} \mathrm{~N} / \mathrm{fed})$ and four levels of elemental sulphur $(0,50$, 100 and $150 \mathrm{~kg} \mathrm{~S} / \mathrm{fed}$ ) was laid out in split plot design with three replications assigning nitrogen levels in main plots and elemental sulphur levels in sub plots. Randomized soil surface samples $(0-30 \mathrm{~cm})$ were taken from the experimental site before sowing and prepared to determine some physical and chemical properties according to Page et al. (1982) and Klute (1986) as shown in Table (1). In both seasons, big to medium size cloves were planted during middle of October, in $3.0 \mathrm{~m} \times 3.5 \mathrm{~m}$ plots, at $20 \times 15$ $\mathrm{cm}$ spacing accommodating 350 plants per plot. The doses of fertilizers were adjusted with the application of ammonium nitrate $(33.5 \% \mathrm{~N}), \quad 200 \mathrm{~kg}$ of calcium superphosphate $\left(15 \% \mathrm{P}_{2} \mathrm{O}_{5}\right)$ and $100 \mathrm{Kg}$ of potassium sulphate $\left(50 \% \mathrm{~K}_{2} \mathrm{O}\right)$. Different doses of nitrogen in the treatments were given in 3 split doses, one third applied with full dose of phosphate, potassium and elemental sulphur and the remaining two third at 40 and 60 days after planting in two equal splits. Harvesting was done during the end of March in both seasons.

\section{Data recorded Yield and its components:}

At harvest time, all plants of each plot were cured, 15 days after harvest weighed in $\mathrm{kg}$ and recorded as total yield (ton/fed). A random sample (10 plants) was taken from each treatment to determine plant height, number of leaves/plant, bulb weight and diameter, as well as the number of cloves/bulb and clove weight. 
Table 1: Physical and chemical properties of the experimental soil.

\begin{tabular}{|c|c|}
\hline Property & Value \\
\hline \multicolumn{2}{|l|}{ Particle size distribution (\%) } \\
\hline Sand & 60.70 \\
\hline Silt & 21.80 \\
\hline Clay & 17.50 \\
\hline Texture grade & Sandy loam \\
\hline $\mathrm{pH}(1: 2.5$ soil water suspension) & 7.68 \\
\hline EC (dS/m, 1:5, soil: water extract.) & 0.72 \\
\hline \multicolumn{2}{|l|}{ Soluble cations (meq/L) } \\
\hline $\mathrm{Ca}^{++}$ & 2.85 \\
\hline $\mathrm{Mg}^{++}$ & 1.97 \\
\hline $\mathrm{Na}^{+}$ & 1.85 \\
\hline $\mathrm{K}^{+}$ & 0.50 \\
\hline \multicolumn{2}{|l|}{ Soluble anions (meq/L) } \\
\hline $\mathrm{CO}^{--}$ & 0.00 \\
\hline $\mathrm{HCO}^{-}$ & 1.23 \\
\hline $\mathrm{Cl}^{-}$ & 3.42 \\
\hline $\mathrm{SO} 4^{--}$ & 2.52 \\
\hline Organic matter (\%) & 0.60 \\
\hline \multicolumn{2}{|l|}{ Available nutrient $(\mathrm{mg} / \mathrm{kg})$} \\
\hline $\mathrm{N}$ & 40.0 \\
\hline$P$ & 7.50 \\
\hline K & 189.4 \\
\hline \multicolumn{2}{|l|}{ DTPA-extractable (mg/kg) } \\
\hline $\mathrm{Fe}$ & 3.80 \\
\hline $\mathrm{Mn}$ & 2.55 \\
\hline $\mathrm{Zn}$ & 0.85 \\
\hline
\end{tabular}

\section{Chemical analysis:}

Concentrations of nutrients, namely, nitrogen, phosphorus and potassium were analyzed from matured bulbs. Five clean sample bulbs from each plot were collected randomly. The cloves were ground, and oven dried at $65^{\circ} \mathrm{C}$ for $48 \mathrm{~h}$. The finely ground and dried tissues were wet digested as described by Wolf (1982). Total $\mathrm{N}$ was determined using the modified micro Kjeldhal method (Cottenie et al. 1982) and $\mathrm{P}$ by colorimetric method using spectrophotometer Ryan et al. (1996). Potassium content was measured using a 
flame photometer method as described by Chapman and Pratt (1982). Protein contents of garlic bulbs were determined in terms of the garlic bulbs nitrogen content multiplied by 6.25 (AOAC, 1994).

\section{Determination of allicin}

Ten bulbs per plot were stored after harvest for investigating changes in the allicin content during storage. Storage was performed for 12 weeks at a constant temperature of $20^{\circ} \mathrm{C}$ in a dry and shaded room, which corresponds with common storage conditions in households.

\section{Allicin extraction}

The outer skin of the garlic cloves was peeled and crushed in a garlic press. The pressed garlic was then collected in a beaker and mixed thoroughly. 700-900 mg of the pressed mash was weighed and transferred to a $50 \mathrm{ml}$ centrifuge tube. Using a volumetric pipette, $25 \mathrm{ml}$ of cold water was delivered to the sample and immediately capped and shaken vigorously for 30 seconds. Heat transfer from hands was avoided by holding the tube cap while shaking. An additional $25 \mathrm{ml}$ of cold water was added and shaken for 30 more seconds to dilute and mix the solution. Each sample is filtered through $0.45 \mu \mathrm{m}$ glass filter into High - performance liquid chromatography (HPLC) vial and capped for injection. Allicin content was extracted and determined according to (Hoppe et al.1996). The first sampling was carried out after 2 week of storage, then after 4, 6, 8, 10 and 12 weeks.

\section{Weight loss during storage}

The weight loss percentage of bulbs was calculated after 6 months of storage which is a factor of the differences between the initial and final weight divided by its initial weight multiplied by 100 .

Data obtained during the two seasons of the study were statistically analyzed according to Gomez and Gomez (1984).

\section{RESULTS AND DISCUSSION \\ I-Effect of different doses of nitrogen and sulphur on yield and yield contributing characters of garlic}

The data presented in Table (2), showed that all the studied growth parameter and bulb yield were significantly increased by increasing the tested levels of both $\mathrm{N}$ and $\mathrm{S}$ fertilizers. The increasing trend of plant height was observed (from 64.16 to $71.53 \mathrm{~cm}$ ) with the increasing level of sulphur from zero to $150 \mathrm{~kg} \mathrm{fed}^{-1}$ but in case of nitrogen, plant height increased from 57.90 to $77.92 \mathrm{~cm}$ with the increasing level from 90 $\mathrm{kg} \mathrm{fed}^{-1}$ to $150 \mathrm{fed}^{-1}$. The maximum plant height $(80.91 \mathrm{~cm})$ was recorded by $\mathrm{N}_{150} \mathrm{~S}_{150}$ followed by $\mathrm{N}_{150} \mathrm{~S}_{100}(78.90 \mathrm{~cm})$ and $\mathrm{N}_{150} \mathrm{~S}_{50}$ $(77.03 \mathrm{~cm})$ as compared to $\mathrm{N}_{90} \mathrm{~S}_{0}(52.64 \mathrm{~cm})$.

In respect of leaf number/plant, the significant variations due to $\mathrm{N}$ and/or $\mathrm{S}$ levels were also observed. The leaf number increased from 9.13 to 10.89 and 8.83 to 11.23with increasing $S$ from $S_{0}$ to $S_{150}$ and $N$ from $N_{90}$ to $N_{150}$ respectively. In different combinations of sulphur and nitrogen the maximum leaf number (11.96) was noticed by $\mathrm{N}_{150} \mathrm{~S}_{150}$ which was at par (11.84) with that of $\mathrm{N}_{150} \mathrm{~S}_{100}$ followed by $\mathrm{N}_{150} \mathrm{~S}_{50}$ (10.71).

In response of bulb diameter, significant variations were detected by $\mathrm{N}$ and/or application. The diameter increased from $5.34 \mathrm{~cm}$ to $5.83 \mathrm{~cm}$ with the increasing level of sulphur from zero to $150 \mathrm{~kg} \mathrm{fed}^{-1}$ and from $4.97 \mathrm{~cm}$ to $6.20 \mathrm{~cm}$ when $\mathrm{N}$ level increased from $90 \mathrm{~kg} \mathrm{fed}^{-1}$ to $150 \mathrm{fed}^{-1}$. Higher values were recorded with the combined higher levels of sulphur and nitrogen.

In case of bulb weight the significant variations were observed by both $\mathrm{N}$ and $\mathrm{S}$ applied individually or in combinations. The bulb weight increased from $70.37 \mathrm{~g}$ to $78.82 \mathrm{~g}$ with increasing level of sulphur (from 0 to $150 \mathrm{~kg} \mathrm{fed}^{-1}$ ) and increased from $63.20 \mathrm{~g}$ to $86.12 \mathrm{~g}$ with increasing $\mathrm{N}$ level from $90 \mathrm{~kg}$ 


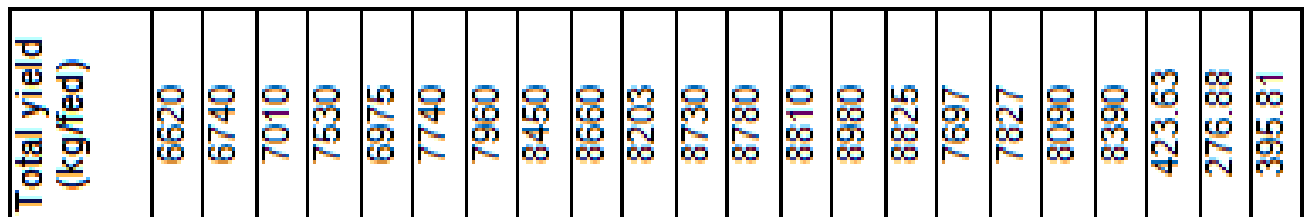

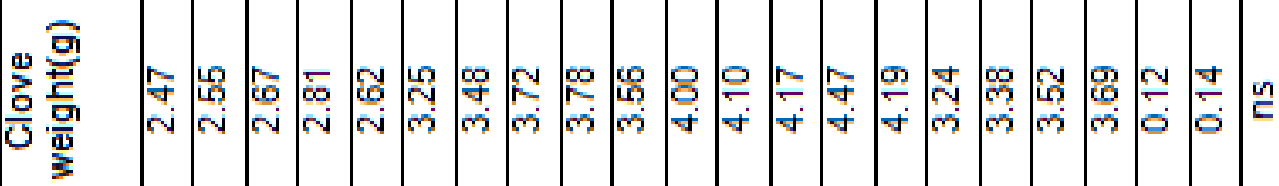

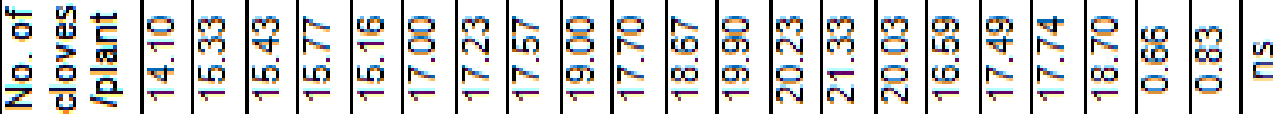

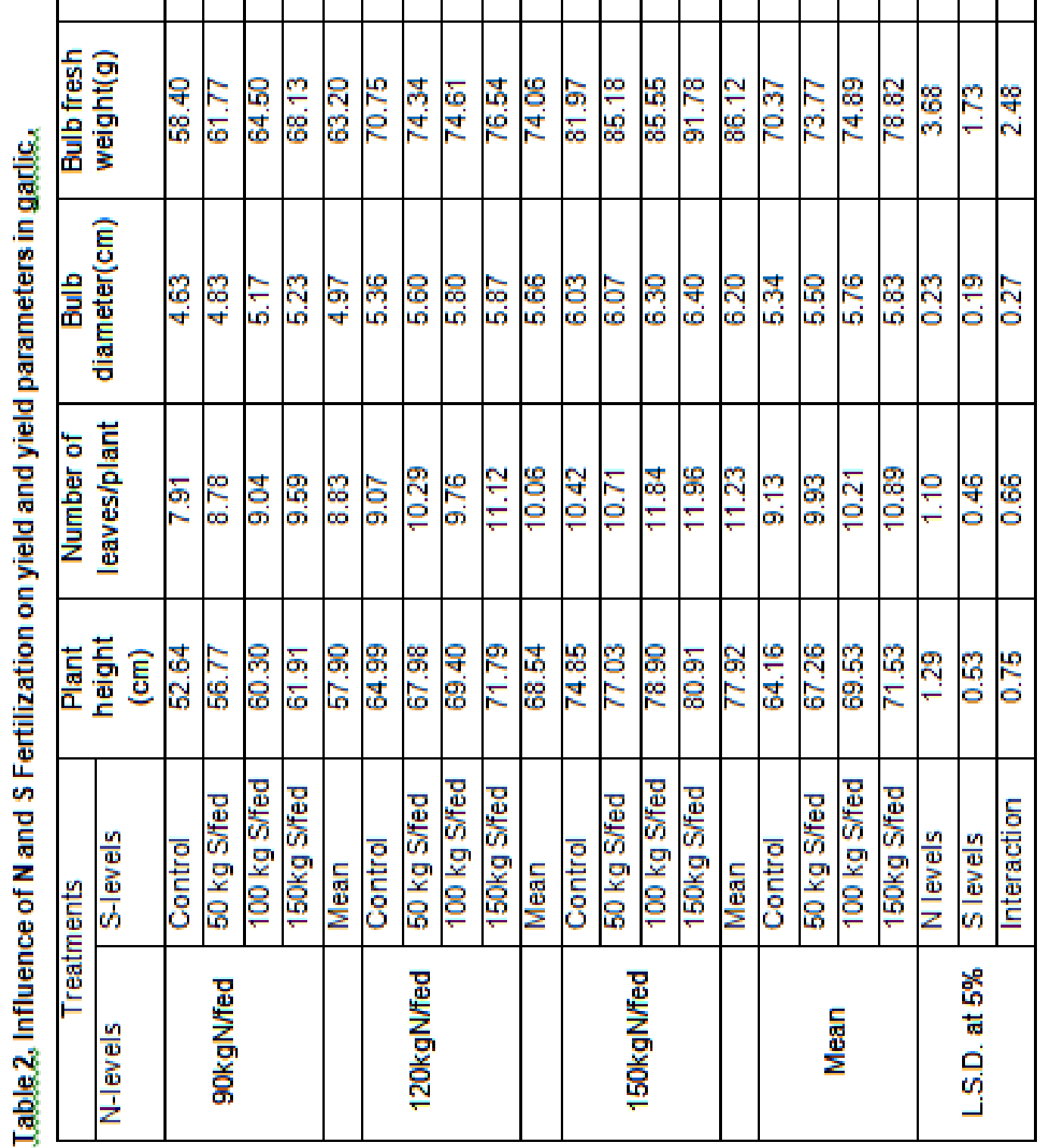


fed $^{-1}$ to $150 \mathrm{fed}^{-1}$. The interaction effects indicated that the maximum bulb weight was recorded in $\mathrm{N}_{150} \mathrm{~S}_{150}(91.78 \mathrm{~g})$ followed by $\mathrm{N}_{150} \mathrm{~S}_{100}(85.55 \mathrm{~g})$ which was at par with $\mathrm{N}_{150} \mathrm{~S}_{50}(85.18 \mathrm{~g})$.

The number of cloves per bulb varied significantly with individual effects only. The clove number increased from 16.59to 18.70 with increasing level of sulphur from zero to $150 \mathrm{~kg} \mathrm{fed}^{-1}$. Increasing level of nitrogen from $90 \mathrm{~kg} \mathrm{fed}^{-1}$ to $150 \mathrm{fed}^{-1}$ caused increase in number of cloves/plant from 15.16 to 20.03.

In case of individual effect of sulphur the clove weight increased from $3.24 \mathrm{~g}$ to $3.69 \mathrm{~g}$ with increasing $S$ dose from zero to $150 \mathrm{~kg}$ fed ${ }^{-1}$ but for nitrogen the clove weight increased from $2.62 \mathrm{~g}$ to $4.19 \mathrm{~g}$ with increasing $\mathrm{N}$ rate from $90 \mathrm{~kg} \mathrm{fed}^{-1}$ to $150 \mathrm{fed}^{-}$ ${ }^{1}$. As for interaction, maximum clove weight was noticed with $\mathrm{N}_{150} \mathrm{~S}_{150}(4.47 \mathrm{~g})$.

Perusal of data presented in Table (2), clearly demonstrated that bulb yield varied significantly by $\mathrm{N}$ and $\mathrm{S}$ levels applied alone or in combination. Increased trend in yield was recorded up to $150 \mathrm{~kg} \mathrm{~N}$ or $\mathrm{S} / \mathrm{fed}$. Yield increased from $7697 \mathrm{~kg} \mathrm{fed}^{-1}$ to $8390 \mathrm{~kg}$ $\mathrm{fed}^{-1}$ and from $6975 \mathrm{~kg} \mathrm{fed}^{-1}$ to $8825 \mathrm{~kg} \mathrm{fed}^{-1}$ with increasing level of sulphur from zero to $150 \mathrm{~kg} \mathrm{fed}^{-1}$ and nitrogen from $90 \mathrm{~kg} \mathrm{~N} \mathrm{fed}^{-1}$ to $150 \mathrm{kgN} \mathrm{fed}^{-1}$. In interactions, maximum yield of $8980 \mathrm{~kg} \mathrm{fed}^{-1}$ was recorded in $\mathrm{N}_{150} \mathrm{~S}_{150}$ combination followed by $\mathrm{N}_{150} \mathrm{~S}_{100}$ $\left(8810 \mathrm{~kg} \mathrm{fed}^{-1}\right)$ and $\mathrm{N}_{150} \mathrm{~S}_{50}\left(8780 \mathrm{~kg} \mathrm{fed}^{-1}\right)$. The minimum yield of $6620 \mathrm{~kg} \mathrm{fed}^{-1}$ was recorded in $\mathrm{N}_{90} \mathrm{~S}_{0}$ combination. The increase in bulb yield of garlic in sulphur applied plots might be due to higher production of metabolites and increase in meristematic activity. Besides, it could be attributed to improvement in nutritional environment in crop root zone and ultimately resulted in better vegetative growth and finally the bulb yield. Similar results were also reported by Channagoudra, (2004); Nasreen et al.
(2007) and Channagouda et al. (2009). The increase in growth characters with the application of sulphur might be due to the favorable effect of sulphur on reducing soil $\mathrm{pH}$, increasing soli particles, thereby improving soil structure and increasing the availability of certain plant nutrients in soil (Nagaich et al. 1999). The results are in conformity with those of Nasreen et al. (2007).

The findings of this investigation with $\mathrm{N}$ effect on garlic plant growth and yield are in close conformity with those of Naruka and Dhaka (2001), Yadav (2003) and Nasreen et al. (2007). Such increasing in morphological parameters of garlic plants as a result of increasing the level of nitrogen application may be attributed to the main role of nitrogen in increasing the merstematic activity, cell division and cell elongation as well as formation of proto-plasmic bulk which consequently affected growth of plants. Availability of nitrogen is prime importance for growing plants as it is major and indispensable constituent of protein and nucleic acid molecules. An adequate supply of nitrogen is associated with vigorous vegetative growth and more efficient use of available inputs finally leading to higher productivity.

\section{II-Protein and nutrient uptake in garlic bulbs *protein content and yield}

Crude protein content in garlic varied significantly with individual effects and in interactions (Table 3). Protein content increased from $11.79 \%$ to $13.13 \%$ with increasing level of sulphur from zero to 150 $\mathrm{kg} \mathrm{fed}^{-1}$. Increasing level of nitrogen from 90 $\mathrm{kg} \mathrm{fed}^{-1}$ to $150 \mathrm{~kg} \mathrm{fed}^{-1}$ caused an increase in protein content from $10.27 \%$ to $15.77 \%$. In interactions, all possible combinations of $\mathrm{N}$ and $S$ levels up to $150 \mathrm{~kg} / \mathrm{fed}$. for each increased protein content generally. The maximum protein content was noticed in 


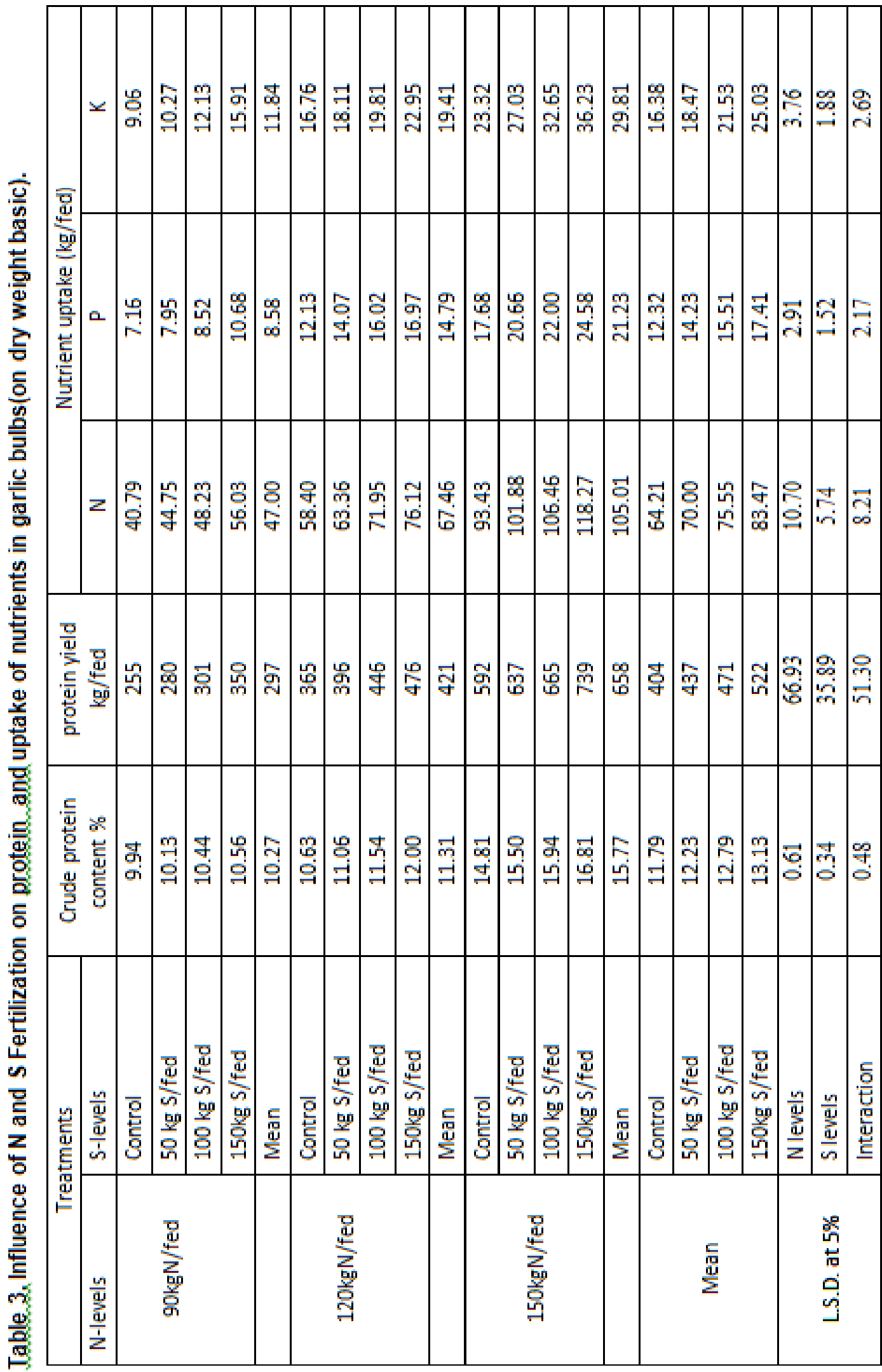


$\mathrm{N}_{150} \mathrm{~S}_{150} \quad(16.81 \%)$ followed by $\mathrm{N}_{150} \mathrm{~S}_{100}$ $(15.94 \%)$ while the minimum protein content $(9.94 \%)$ was noticed with $\mathrm{N}_{90} \mathrm{~S}_{0}$. More increases in crude protein content were detected by combined application of $\mathrm{N}$ and $S$ thereby showing a synergistic relationship between $\mathrm{N}$ and $\mathrm{S}$ in garlic. The increase in growth, bulbs yield and crude protein might be attributed to increased photosynthetic and meristematic activities of plant and improvement in the synthesis of protein and amino acids in the presence of adequate available $\mathrm{N}$ supply.

Protein yield increased from $404 \mathrm{~kg} \mathrm{fed}^{-1}$ to $522 \mathrm{~kg} \mathrm{fed}^{-1}$ and from $297 \mathrm{~kg} \mathrm{fed}^{-1}$ to 658 $\mathrm{kg} \mathrm{fed}^{-1}$ with increasing level of sulphur from zero to $150 \mathrm{~kg} \mathrm{fed}^{-1}$ and nitrogen from $90 \mathrm{~kg}$ $\mathrm{fed}^{-1}$ to $150 \mathrm{fed}^{-1}$. Maximum protein yield $\left(739 \mathrm{~kg} \mathrm{fed}^{-1}\right)$ was recorded in $\mathrm{N}_{150} \mathrm{~S}_{150}$ combination followed by $\mathrm{N}_{150} \mathrm{~S}_{100}$ ( $665 \mathrm{~kg}$ fed $\left.{ }^{-1}\right)$ and $\mathrm{N}_{150} \mathrm{~S}_{50}\left(637 \mathrm{~kg} \mathrm{fed}^{-1}\right)$. The minimum yield of $\left(255 \mathrm{~kg} \mathrm{fed}^{-1}\right)$ was recorded in $\mathrm{N}_{90} \mathrm{~S}_{0}$ combination.

\section{*Nutrient Uptake in garlic bulbs}

The value of nutrient uptake followed the pattern of yield obtained in different treatments (Table 3). The $\mathrm{N}$ uptake in cloves significantly increased from $47 \mathrm{~kg}$ /fed to $105.01 \mathrm{~kg} / \mathrm{fed}$ with increasing nitrogen levels from $90 \mathrm{~kg} \mathrm{fed}^{-1}$ to $150 \mathrm{fed}^{-1}$ and from $64.21 \mathrm{~kg} \mathrm{fed}^{-1}$ to $83.47 \mathrm{~kg} \mathrm{fed}^{-1}$ with increasing sulphur levels from zero to $150 \mathrm{~kg}$ $\mathrm{fed}^{-1}$. Maximum $\mathrm{N}$ uptake $\left(118.27 \mathrm{~kg} \mathrm{fed}^{-1}\right)$ was recorded with $\mathrm{N}_{150} \mathrm{~S}_{150}$ combination followed by $\mathrm{N}_{150} \mathrm{~S}_{100}\left(106.46 \mathrm{~kg} \mathrm{fed}^{-1}\right)$ and $\mathrm{N}_{150} \mathrm{~S}_{50}\left(101.88 \mathrm{~kg} \mathrm{fed}^{-1}\right)$.

The uptake of $\mathrm{P}$ in cloves was significantly higher with all the treatments. Increasing levels of $N$ fertilizers from $90 \mathrm{~kg}$ fed $^{-1}$ to $150 \mathrm{fed}^{-1}$ increased $\mathrm{P}$ uptake from $8.58 \mathrm{~kg} / \mathrm{fed}$ to $21.23 \mathrm{~kg} / \mathrm{fed}$ and from $12.32 \mathrm{~kg} \mathrm{fed}^{-1}$ to $17.41 \mathrm{~kg} \mathrm{fed}^{-1}$ with increasing level of sulphur from zero to 150 $\mathrm{kg} \mathrm{fed}^{-1}$ which may be due to better growth and dry matter production of plants and a deeper ramification of roots which causes higher uptake of phosphorus. In the interaction, effect show that maximum $p$ uptake (24.58 kg fed ${ }^{-1}$ ) was recorded in $\mathrm{N}_{150} \mathrm{~S}_{150}$ combination which may be attributed to beneficial effect of this treatment on availability of $\mathrm{P}$ in soil (Singh et al. 1996) followed by $N_{150} S_{100}\left(22.00 \mathrm{~kg} \mathrm{fed}^{-1}\right)$ and $\mathrm{N}_{150} \mathrm{~S}_{50}\left(20.66 \mathrm{~kg} \mathrm{fed}^{-1}\right)$. The minimum Puptake of $\left(7.16 \mathrm{~kg} \mathrm{fed}^{-1}\right)$ was recorded in $\mathrm{N}_{90} \mathrm{~S}_{0}$ combination. These results may be due to that application of sulphur helps in the availability of other nutrients resulting in better growth and increased uptake of all the nutrients at higher levels of sulphur. Similar results have been reported by Dabhi et al. (2004); Jaggi (2005) and Nasreen et al. (2007). The positive effect of sulphur may be due to lowering soil $\mathrm{pH}$ factors that improved soil structure, soil chemical properties and increased the availability of certain plant nutrients such as $\mathrm{P}$ and better biochemical activity in the crop plants Singh and Singh (2005).

In case of potassium uptake the significant variations were observed with both individual and combination treatments. K-uptake increased from $16.38 \mathrm{kgfed}^{-1}$ to $25.03 \mathrm{kgfed}^{-1}$ with increasing level of sulphur from 0 to $150 \mathrm{~kg} \mathrm{fed}^{-1}$ and increased from $11.84 \mathrm{~kg} \mathrm{fed}^{-1}$ to $29.81 \mathrm{~kg} \mathrm{fed}^{-1}$ with increasing $\mathrm{N}$ level from $90 \mathrm{~kg} \mathrm{Nfed}^{-1}$ to 150 $\mathrm{kgN} \mathrm{fed}{ }^{-1}$. Meanwhile, maximum K- uptake (36.23kg fed ${ }^{-1}$ ) was recorded in $\mathrm{N}_{150} \mathrm{~S}_{150}$ followed by $\mathrm{N}_{150} \mathrm{~S}_{100}\left(32.65 \mathrm{~kg} \mathrm{fed}^{-1}\right)$ and $\mathrm{N}_{150} \mathrm{~S}_{50}\left(27.03 \mathrm{~kg} \mathrm{fed}^{-1}\right)$. The minimum Kuptake of $9.06 \mathrm{~kg} \mathrm{fed}^{-1}$ was recorded in $\mathrm{N}_{90} \mathrm{~S}_{0}$ combination. This might be due to greater vegetative growth, translocation of stored material and cloves production. Similar findings were reported by Jaggi (2005). Sulphur fertilizer might have promoted the availability of native soil nutrients as reflected by their uptake. Similar opinion was reported by Nasreen et al. (2007). 


\section{III-Changes in Allicin Content during post- harvest storage in relation to $N$ and $S$ Fertilization}

Intact garlic cells contain (+)-S-allyl- Lcysteine sulfoxide, an odorless compound known as alliin. When cell lysis occurs, the enzyme alliinase stored in vacuoles inside the cells is released, and when it comes in contact with alliin, it is converted into allicin (diallyl thiosulfinate) fig. (1 and 2). Allicin decomposes in the presence of air and water producing mainly diallyl disulfides (responsible for the characteristic odor of garlic). The same degradation process occurs in the body, and it is associated with the characteristic odor in breath after garlic ingestion (Ichikawa et al. 2006).

The amount of alliin is an important criterion for assessing the quality of the different commercial varieties of garlic since it is directly related to the state of freshness and appropriate conservation techniques. S fertilization was shown to increase a broad range of S-containing metabolites in plants such as cysteine, glutathione, and glucosinolates as well as cysteine sulfoxides in Allium species. Allicin increased from 13.87in control plots to $26.59 \mathrm{mg} \quad \mathrm{g}^{-1}$ dry weight at the highest $S$ rate in garlic cloves after 2 weeks of storage and from 3.23to $7.95 \mathrm{mg} \mathrm{g}-1$ dry weight after 12 weeks of storage period with increasing level of sulphur from zero to $150 \mathrm{~kg} \mathrm{fed}^{-1}$. The control and lowest $S$ application rate of 50 $\mathrm{kg} S \mathrm{fed}^{-1}$ showed a reduced allicin concentration after 12 weeks of storage when compared to that of the plots which received either 100 or $150 \mathrm{~kg} \mathrm{~S} \mathrm{fed}^{-1}$ (Table 4 and fig. 3) Allicin decreased gradually in the garlic cloves during the storage period up to 12 weeks however, it was increased by increasing $\mathrm{S}$ and/or $\mathrm{N}$ levels. Increasing level of nitrogen from $90 \mathrm{~kg} \mathrm{fed}^{-1}$ to $150 \mathrm{fed}^{-}$ ${ }^{1}$ caused an increase in allicin content from 10.55 to $16.77 \mathrm{mg} \mathrm{g}^{-1}$ dry weight after

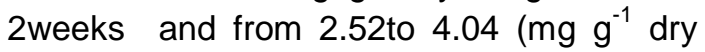
weight) after 12 weeks of storage period (fig. 4). The interactions effect showed that the maximum allicin content was noticed in $\mathrm{N}_{150}$ $\mathrm{S}_{150}$ treatment (28.88mg $\mathrm{g}^{-1}$ dry weight) followed by $\mathrm{N}_{150} \mathrm{~S}_{100}$ treatment $\left(26.62 \mathrm{mg} \mathrm{g}^{-1}\right.$ dry weight). In this regard (Bloem et al.2004) reported that an increase in S supply is

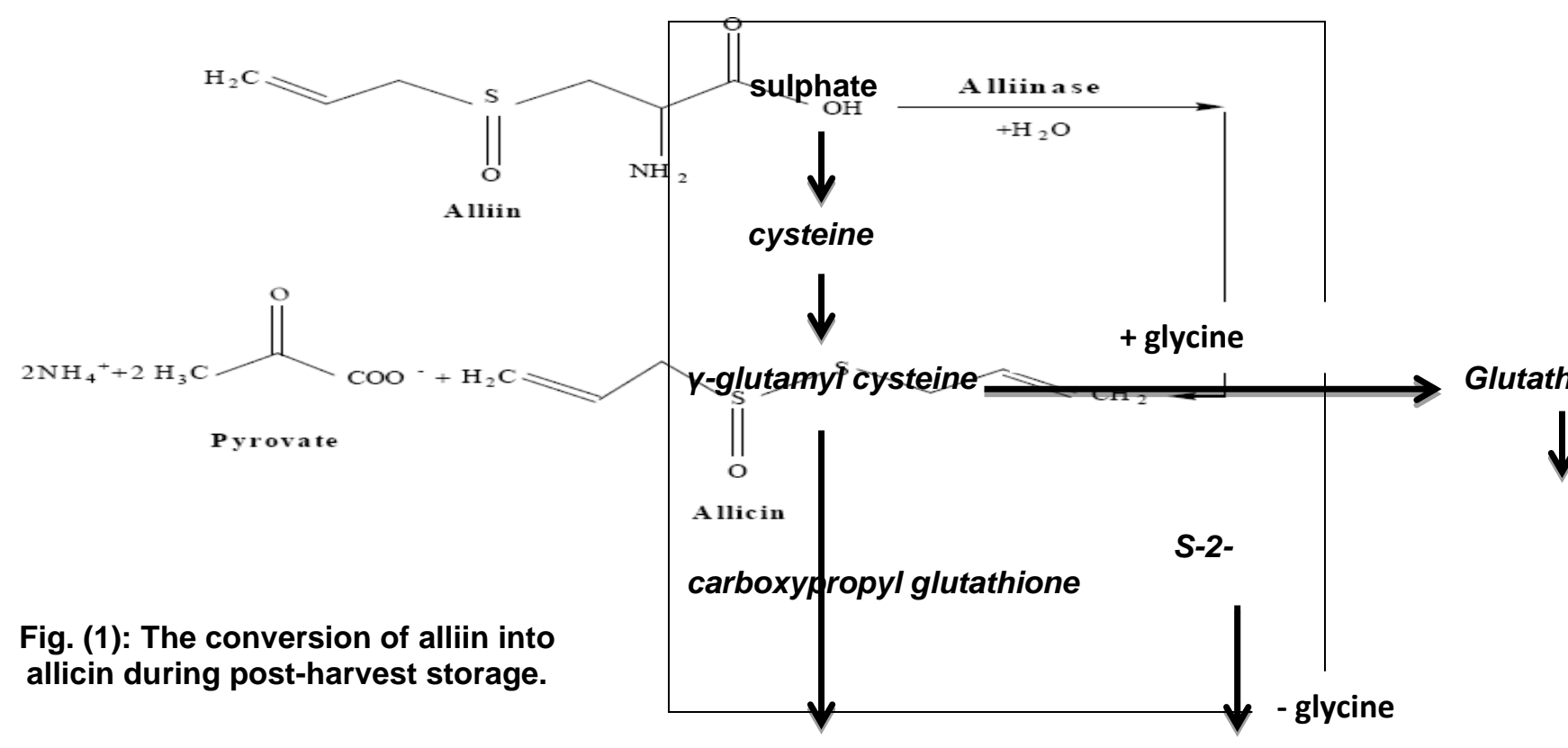


Ewais, et al.,

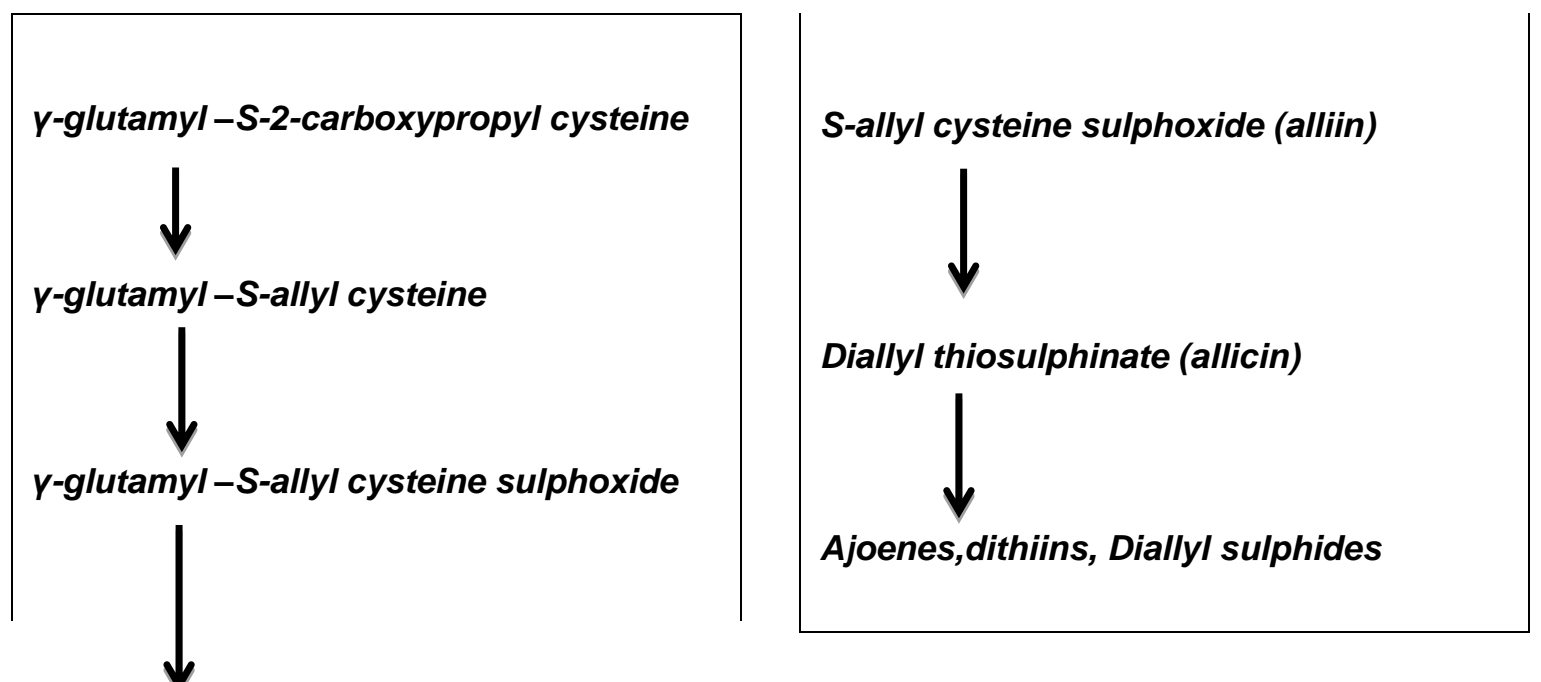




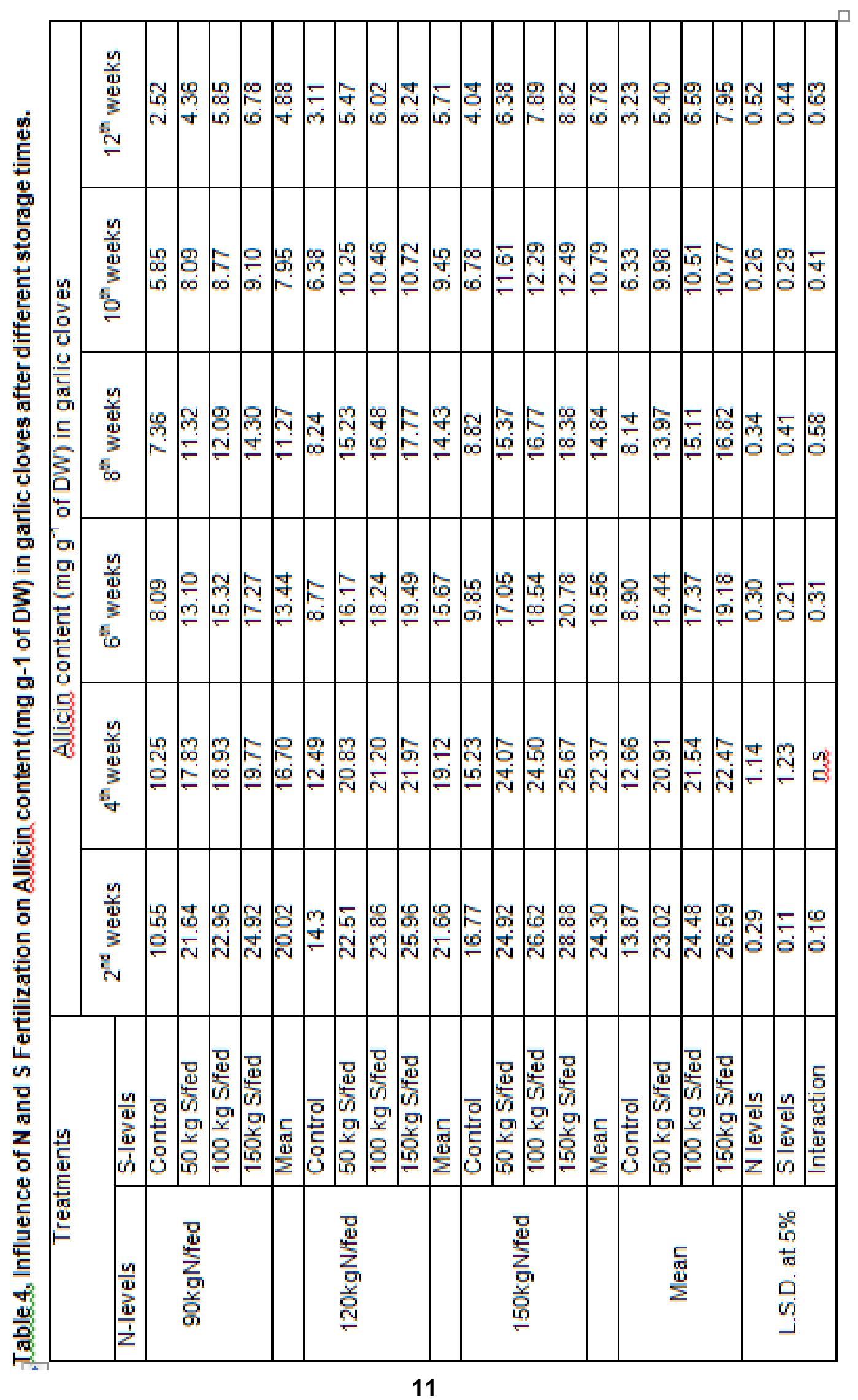


Ewais, et al.,

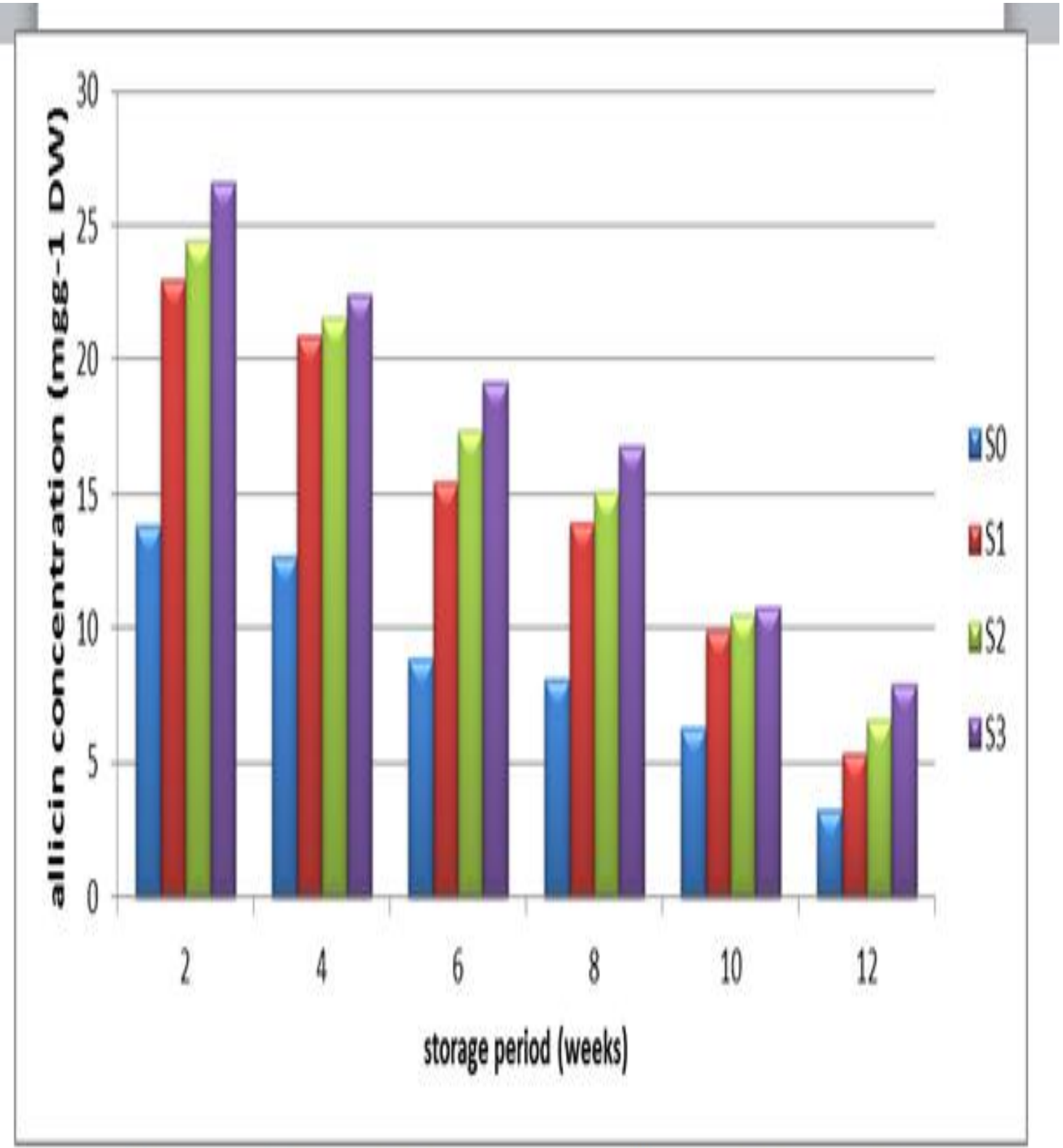

Fjgure 3 Effect of S fertilization on change in allicin concentration of garlic cloves with storage time

generation of sulphurcontaining flavor compounds and their respective precursors in garlic, Allium sativum $\mathrm{L}$. 


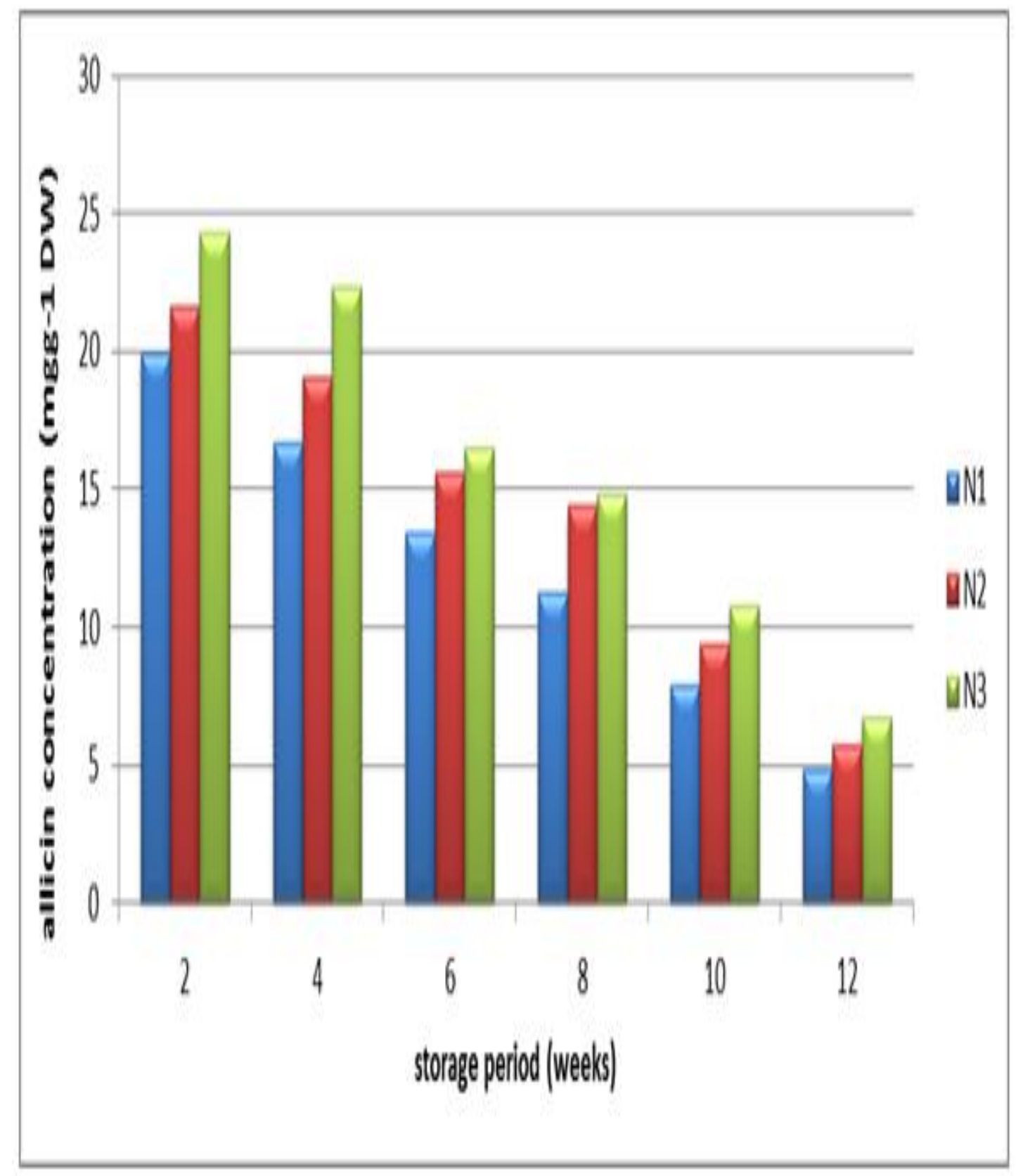

Figure4, Effect of N fertilization on change in allicin concentration of garlic cloves with storage time 
related to an increase in alliin content of leaves and bulbs of garlic crop, whereas nitrogen fertilization has only a minor influence on crop quality. They added that allicin content in bulbs could be doubled by $S$ fertilization. Allicin translocate from leaves to bulbs so, time of harvest has a strong influence on the allicin content. At the beginning of plant development, high allicin contents were found in leaves, while with bulb development, they were translocate into this plant organ.

The results show that the potential health benefits of Allium species could be distinctly improved by $S$ fertilization. This might be due to increased uptake of $S$ by crop due to its application to soil resulting in the increased synthesis of volatile sulphur compounds and production of more pungency in garlic. 'The combination of 150 $\mathrm{kg} \mathrm{N}$ fed $^{-1}$ with $150 \mathrm{~kg} \mathrm{~S}^{-1}$ fed $^{-1}$ recorded the highest allicin content in garlic during 12 weeks of storage period compared to other interactions due to greater supply of nitrogen and sulphur to the garlic crop. Sulphur metabolism is intimately related to nitrogen metabolism through the production of the amino acid cysteine as the first organic sulphur compound in sulphur assimilation. Nitrogen supply may, therefore, have an effect on sulphur uptake and formation of alk(en)yl cysteine sulphoxide flavor precursors (CSOs) Randle et al. (1993).

\section{IV-Cumulative weight loss of garlic bulb during storage.}

The results showed that physiological loss in weight (PLW) of garlic bulbs (Table 5) increased continuously with the increasing of storage period. Garlic bulbs grown with 150 $\mathrm{kg} \mathrm{N} / \mathrm{fed}$ (T9) recorded higher PLW loss and the highest loss (48.33\%) was after 180 days of storage. On the contrary, garlic bulbs harvested from the plot received $\mathrm{N}_{90} \mathrm{~S}_{150}$ combination recorded lower PLW loss $(38.68 \%)$ after 180 days of storage. An increased PLW for all the treatments could be due to rapid loss of moisture and drastic reduction in firmness for the active physiological processes like respiration, transpiration and ethylene production (Kumar et al. 2007). In periodical observation at 30 days interval, it was found that the stored bulbs of all treatments lost weight gradually and the maximum weight loss was recorded after 6 months of storage. Increasing levels of $\mathrm{N}$ fertilizer from $90 \mathrm{~kg} \mathrm{fed}^{-1}$ to $150 \mathrm{kgN} \mathrm{fed}^{-1}$ increased (PLW) during the studied storage period, while $\mathrm{S}$ fertilizations showed the opposite, since PLW was found to be reduced by increasing $S$ fertilizer rate (Figure 5). Comparing the results of different treatments, it can be opined that application of elemental sulphur at $150 \mathrm{kgSfed}^{-1}$ should be made for quality crop with higher yield and better storability of garlic (Figure 6). In interactions, maximum weight loss after 6 months of storage 48.33\%was recorded in $\mathrm{N}_{150} \mathrm{~S}_{0}$ combination followed by $\mathrm{N}_{150} \mathrm{~S}_{50}(46.64 \%)$ and $\mathrm{N}_{120} \mathrm{~S}_{0}$ (46.31\%). The minimum weight loss $38.68 \%$ was recorded in $\mathrm{N}_{90} \mathrm{~S}_{150}$ combination.Loss in weight of bulb is usually known to be occurred due to rotting, dehydration transpiration, respiration, sprouting, etc. (Ullah et al. 2008). The increase in percentage of lost weight bulbs due to increased nitrogen rate could be attributed to the fact that higher rates of nitrogen enhanced plants to produce bulbs bulbs with soft succulent tissues which make them susceptible to the attack by a disease caused by microorganisms and leads to production of bulbs with large neck diameter which are difficult to dry (Gopalkrishnan and Srinivas 1990).. Each increase of $N$ fertilizing dose, was followed by the significant increase of the quantity of rotten bulbs. Practically, the weight of rotten bulbs at the highest $\mathrm{N}$ fertilizer dose was more doubled compared to the least fertilizer dose experimental plots. The water content of garlic is an important quality parameter as 


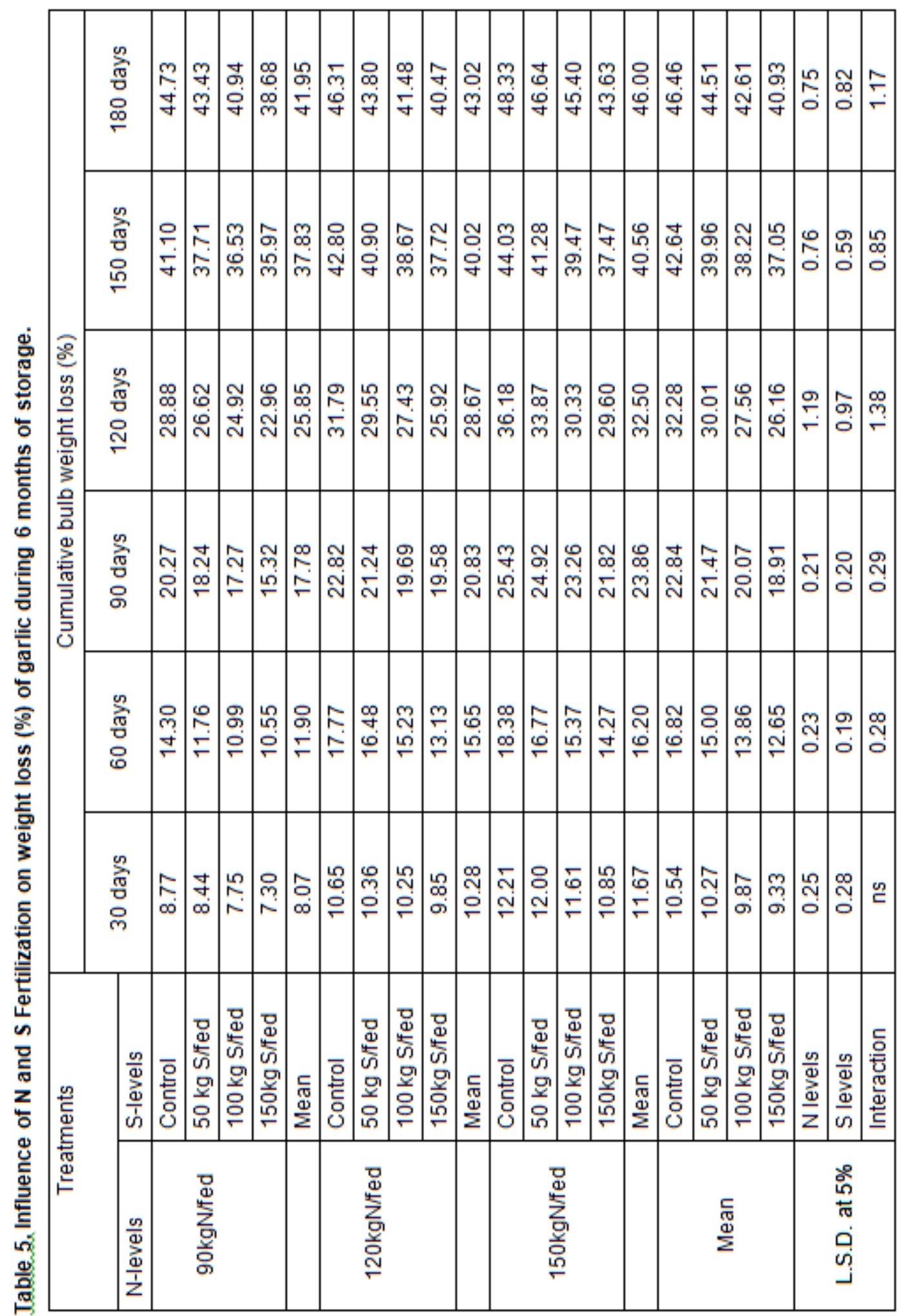


Ewais, et al.,

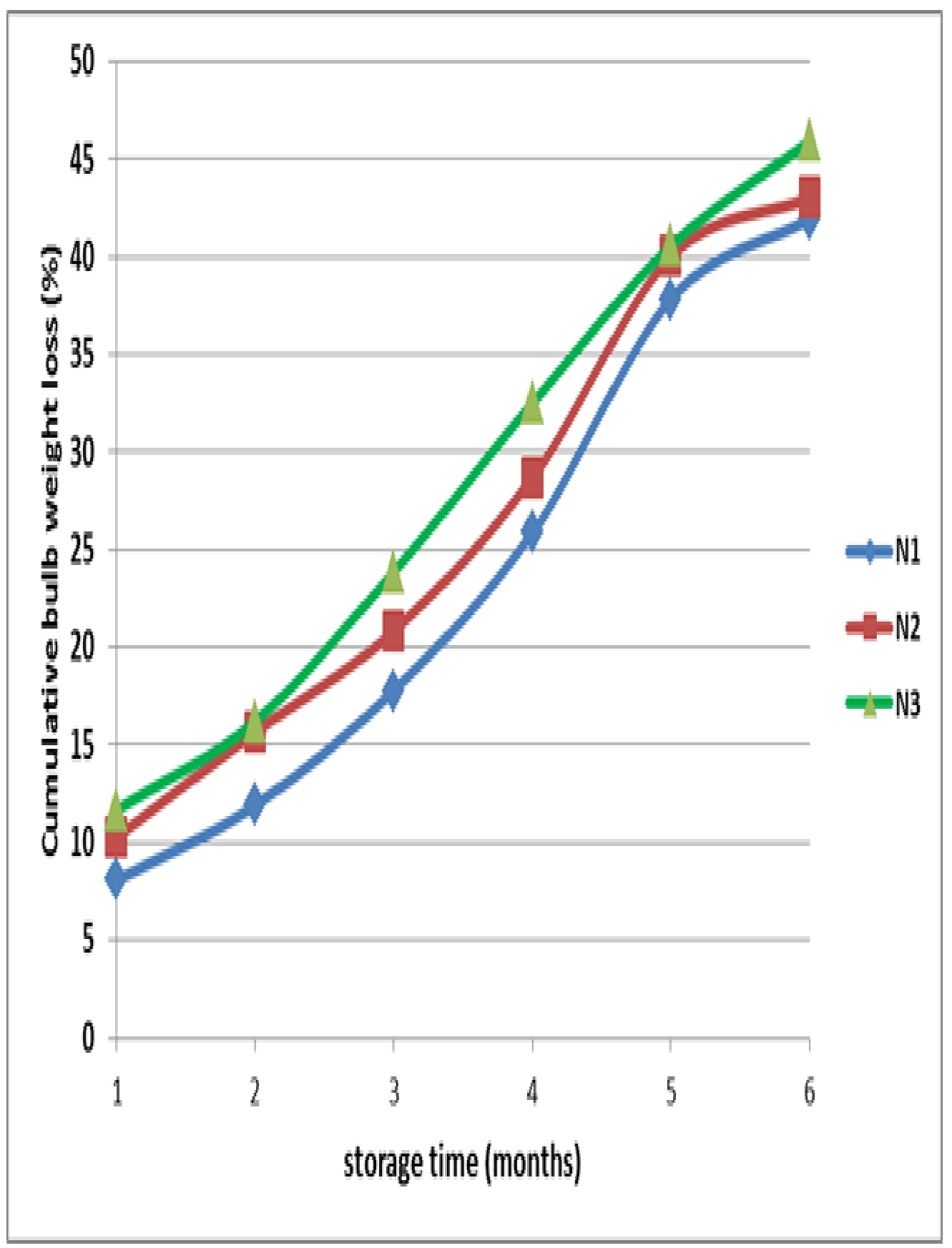

Figure 5, Effect of N Nertillzation on bull weight loss during Storage 


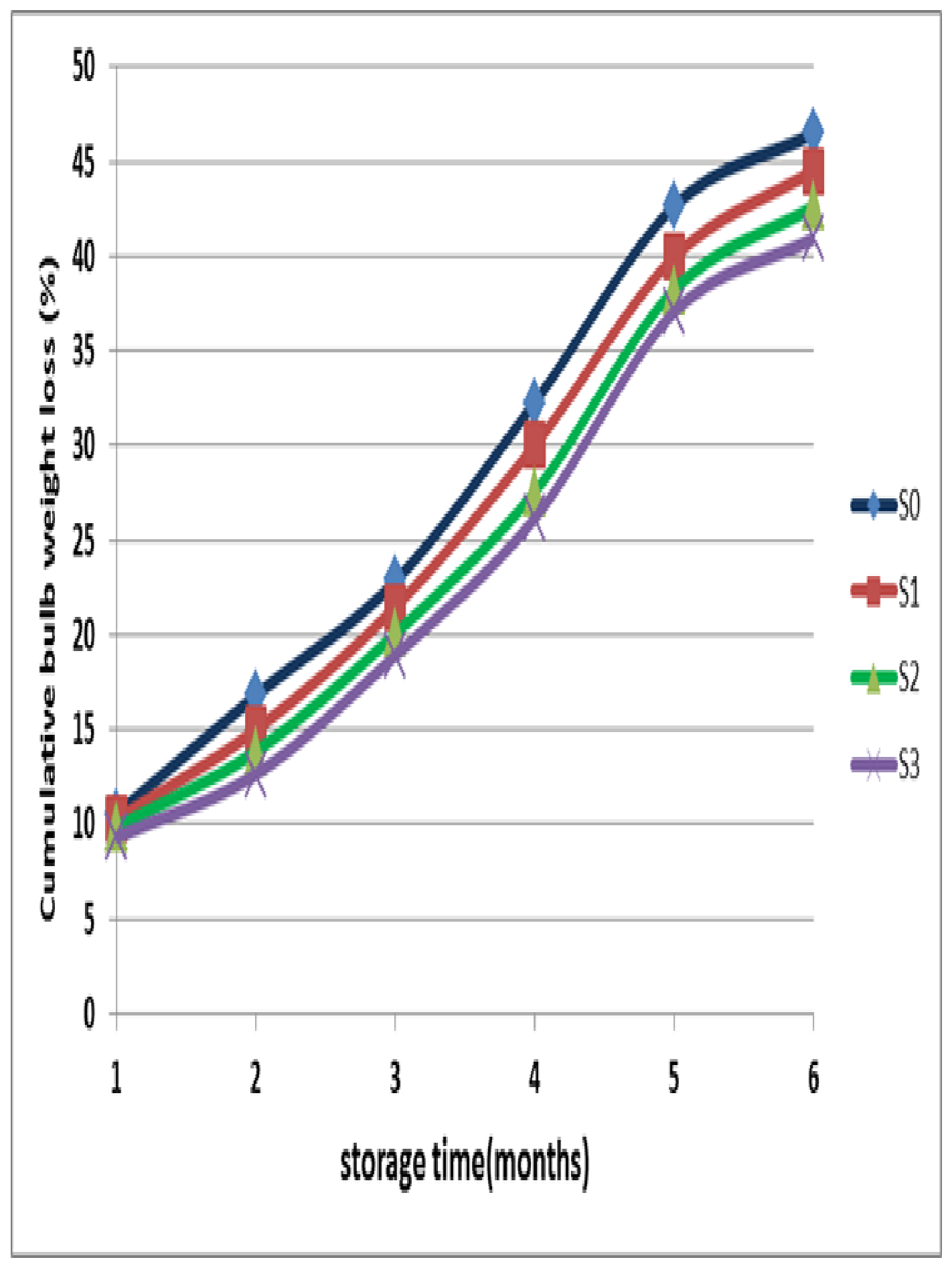

Figure 6 , Effect of $\$$ fertilization on bull weight loss during Storage 
only firm bulbs can be sold. It is known that high $\mathrm{N}$ application rates in the later stages of bulb development of garlic delay maturation and produce soft bulbs with shorter postharvest shelf life. Water losses from intact bulbs are also affected by $\mathrm{N}$ or $\mathrm{S}$ fertilization (Bloem et al. 2004). Water losses from intact bulbs are distinctly higher than water losses from cloves. The reason is that the drying process starts from the outer hulls to the cloves. $S$ fertilization had a more effect on the water content of cloves, though $S$ fertilization significantly increased the $S$ concentration in cloves. The water losses were by trend higher when $\mathrm{S}$ levels were low after 6 months of storage (Table 5). The comparison of the different fertilizer treatments shows that after 6 months of storage $\mathrm{N}$ fertilization had more significant effect on water losses from the plant tissue. In contrast, $S$ fertilization resulted in lower water losses from cloves. This effect was significant and most pronounced when least $\mathrm{N}$ was applied. The data further reveal that a higher $\mathrm{S}$ content may prevent garlic bulbs from shriveling, while a high $\mathrm{N}$ supply may thwart this effect (Woldetsadik et al. 2003).

\section{V -CONCLUSIONS}

The present results demonstrate that garlic bulbs fertilized with a higher level of $S$ have a higher potential to accumulate allicin after harvest, which is important to consider as garlic bulbs are usually stored before usage. A higher $S$ fertilization in combination with lower $\mathrm{N}$ application resulted in high quality firm garlic bulbs, which are preferred by consumers. The result showed that nutrient combination of the garlic bulbs significantly influenced the physiological loss in weight (PLW) and organoleptic quality of garlic bulb and judicious selection of nutrient combination can extend the storage life and reduce the post-harvest deterioration of garlic bulb. The presented results are an important contribution for improving the quality and storage life of fresh garlic.

\section{REFERENCES}

Ajay, K. and O. Singh (1994). Role of sulphur in nutrient utilization and catalase activity in onion crop. Indian J. Agric. Res. 28: 15-19.

AOAC (1994). (Association of Official Analytical Chemist) Official Method of Analysis. $12^{\text {th }} \mathrm{Ed}$. Washington, DC.

Bloem, E., S. Haneklaus and E. Schnug (2004). Influence of nitrogen and sulfur fertilization on the alliin content of onions and garlic. J. Plant Nutr., 27: 1827-1839.

Chapman, H.D. and P.F. Pratt (1982). Methods of Plant Analysis, I. Methods of Anaylsis for Soil, Plant and Water. Chapman Publishers, Riverside, California, USA.

Channagouda, R.F., P. Ajjappalavara and A.S. Kamble (2009). Response of onion (Allium cepa L.) to different levels of irrigation and sulphur in alfisoils of northern transitional tract of Karnataka. Asian J. Hort., 4: 152-55.

Channagoudra, R.F. (2004). Response of onion (Allium cepa L.) to irrigation schedule and sulphur levels in northern transitional zone of Karnataka. M.Sc. (Agri.) Thesis, Univ. of Agri. Sci., Dharwad.

Cottenie, A., M. Verloo, L. Kiekens, G. Velge and R. Camerlynck (1982). "Chemical Analysis of Plants and Soils". Lab.Agrochem,State University Ghent, Belgium.

Dabhi, N. M., M. V. Patel and V. R. Patel (2004). Effect of sources and levels of sulphur on yield and chemical composition of onion in loamy sand. Nat. Semi. on Dev. Soil Sci.: $69^{\text {th }}$ Ann. Con. Hyderabad, October 27-30, p. 124.

Farooqui, M. A., I. S. Naruka, S. S. Rathore, P. P. Singhand and R. P. S. Shaktawat (2009). Effect of nitrogen and sulphur levels on growth and yield of garlic (Allium sativum L.). Aus. J. Food Ag-Ind. Special Issue, pp. 18-23.

Gomez, K.A. and A.A. Gomez (1984). Statistical Procedures for Agricultural Research. 2nd Ed., John Wiley and Sons, New York, USA.

Gopalkrishnan, K. P. and K. Srinivas (1990). "Studies on storage behavior of onion as 
influenced by $\mathrm{N}$ fertilization", Indian Food Packer, 44 (1): 5-11.

Holub, B. J., K. Arnott, J. P. Davis, A. Nagpurkar and J. Peschell (2002). Organosulfur compounds from garlic. In J. Shi, G. Mazza \& M. L. Maguer (Eds.). Functional foods: biochemical and processing aspects (cap. 2, pp. 213-279). Washington: CRC Press.

Hoppe, L., M. Bahadir, S. Haneklaus and E. Schnug (1996). Sulphur Supply and Allicin Content of Allium Species. XXXI. DGQ-Vortragstagung:Kiel, Germany, 189-192.

Ichikawa, M., N. Ide and K. Ono (2006). Changes in Organosulfur compounds in garlic cloves during storage. J. Agric. Food Chem 54: 4849-4854.

Jaggi, R.C. (2005). Sulphur as production and protection agent in onion (Allium cepa L). Indian J. Agric. Sci., 75: 805808.

Klute, A.A. (1986). 'Methods of Soil Analysis". American Society of Agronomy, Inc. Publishers, Madison, Wisconsin, U.S.A., 2nd Edition.

Kumar, S., M. Imtiyaz and A. Kumar (2007). "Effect of differential soil moisture and nutrient regimes on postharvest attributes of onion (Allium cepa L.)", Sci. Hortic., 112: 121-129.

Nagaich, K.N., S.K. Trivedi and R. Lekhi (1999). Effect of sulphur and potassium fertilization in onion (Allium cepa L.). Hort. J., 12: 25-31.

Nasreen, S., S.M.I. Haq, M.A. Hossain and A. Farid (2007). Nutrient uptake and yield of onion as influenced by nitrogen and sulphur fertilization. Bangladesh J. Agric. Res., 32: 413-20.

Naruka, I.S. and R.S. Dhaka (2001). Effect of row spacing and nitrogen fertilization on growth, yield and composition of bulb in garlic (Allium sativum L.) cultivars. J. Spices Aromatic Crops, 10: 111-17.

Naruka, I.S., P.P. Singh, S.S. Rathore and M. Singh (2005). Response of garlic (Allium sativum L.) cultivars to nitrogen fertilization and crop geometry on composition of bulb.In: National Seminar on Agro-technology, Quality,
Processing and Export of Spices J.N.K.V.V. Jabalpur. pp 52.

Page, A. L., R. H. Miller and D. R. Keeny (ed.) (1982). Methods of Soil Analysis, part2. Chemical and Microbiological Properties. Amer. Soc. of Agronomy. Madison, Wisconsin, USA.

Queiroz, Y. S., E. Y. Ishimoto, D. H. M. Bastos, G. R. Sampaio and E. A. F. S. Torres (2009). Garlic (Allium sativum L.) and ready-to eat garlic products: in vitro antioxidant activity. Food Chemistry, 115(1): 371-374.

Randle, W. M. and J. E. Lancaster (2002). Sulphur compounds in alliums in relation to flavour quality. In Allium Crop Science: Recent Advances; Rabinowitch, H. D., Currah, L., Eds.; CABI Publishing: Wallingford, UK; 329-356.

Randle, W. M. and M. L. Bussard (1993). Pungency and sugars of short day onions as affected by sulfur nutrition. J. Am. Soc. Hortic. Sci., 118: 766-770.

Ryan, J., S. Garabet, K. Harmsen and A. Rashid (1996). Soil and Plant Analysis. Manual Adapted for the west Asia and North Africa Region. ICARDA, Aleppo, Syria. 140pp.

Singh, H. and G. Singh (2005). Effect of phosphorus and sulphur on yield, content and uptake of nutrient by garlic. Annals of Agric. Res. New Series 26(1): 48-50.

Singh, H., S. Singh and V. Singh (1996). Response of onion (Allium cepa L.) to nitrogen and sulphur. Annals of Agric. Res. 17 (4): 441-444.

Tepe, B., M. Sokmen, H. A. Akpulat and A. Sokmen (2005). In vitro antioxidant activities of the methanol extracts of five Allium species from Turkey. Food Chemistry, 92(1): 89-92.

Ullah, M. H., S. M. I. Huq, M. D. U Alam and M. A. Rahman (2008). Impacts of sulphur levels on yield, storability and economic return of onion. Bangladesh $\mathrm{J}$. Agric.Reas., 33 (4): 539-548.

Wolf, B. (1982). A comprehensive system of leaf analysis and its use for diagnosing crop nutrients status. Comm. Soil Sci. Plant Anal., 13: 1035-1059. 
Ewais, et al.,

Woldetsadik, K., U. Gertsson and J. Ascard (2003). Shallot yield, quality and storability as affected by irrigation and nitrogen. J Hortic Sci Biotechnol. 78: 549-553.

Yadav, P.K. (2003). Effect of nitrogen and potassium on growth and yield of garlic (Allium sativum L.) in western Rajasthan. Haryana J. Hort. Sci., 32: 290-91.

\section{إستجابة نباتات الثوم للتسميد بالنيتروجين والكبريت}

\section{ماجدة على عويس ، سحرمحمد زكريا ، أمال حسن الجبالى

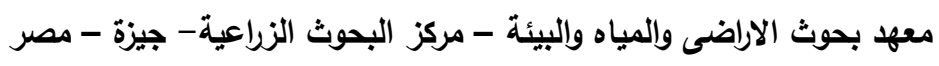

الملخص العربى الثوم هو واحد من أهم محاصيل الخضر فى العالم ذو نكهة مميزة وهو عنصر اساسى من مكونات المطبخ فى العديد من مناطق العالم ولذا فقد اجريت الدراسات الحالية بهدف تقييم مستويات مختلفة من النيتروجين والكبريت على إنتاجية وجودة محصول الثوم حيث اقيمت تجربة حقلية فى محطة بحوت القصاصين بمحافظة الاسماعيلية مصر خلال الموسم الثنتوى

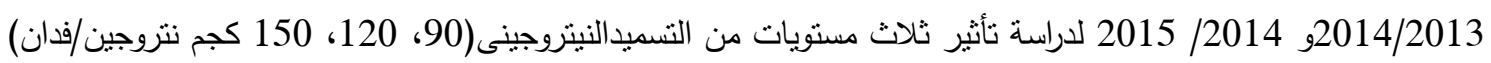

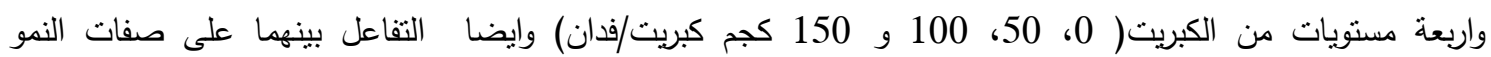
والمحصول والمحتوى الكيماوي للثوم (صنف سدس 40 ) حيث استخدم التصميم الاحصائى للقطع المنشقة فى ثلاث

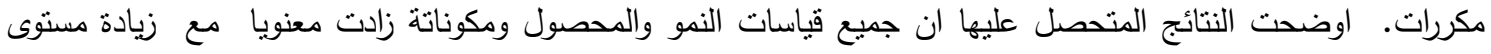

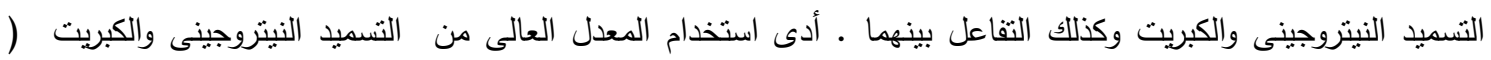
في تحقيق أعلى القيم فى جميع قياسات النمو المدروسة مقارنتة بالمعاملات الاخرى.

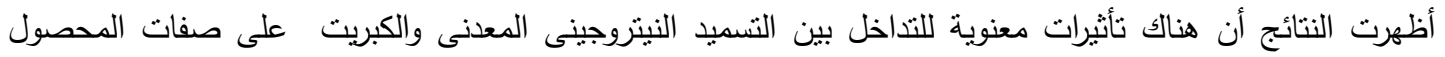

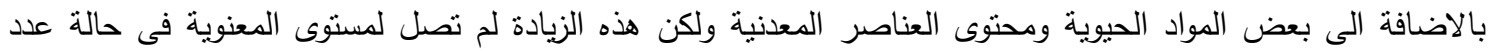

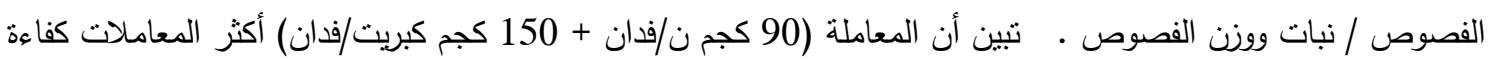

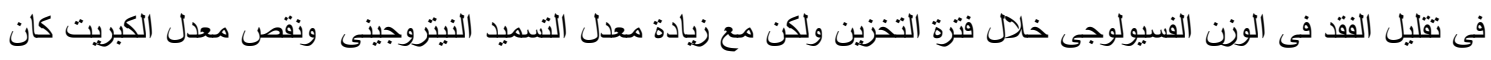

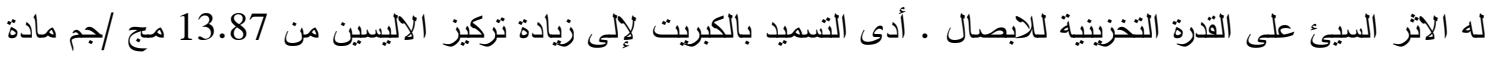

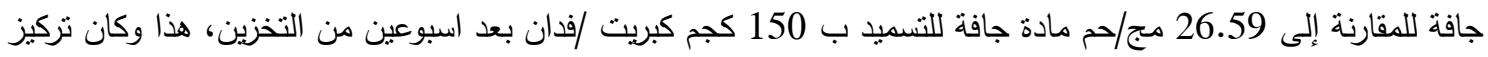

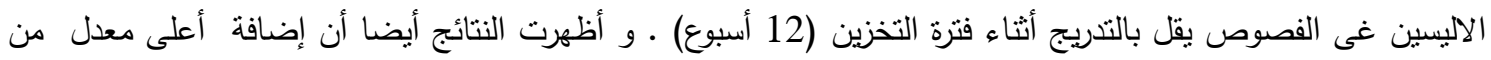
النسميد النيتروجينى والكبريت (150 كجم نتروجين/فدان+150 كجم كبريت/فدان) أعطى أعلى القيم لجميع قياسات المكونات

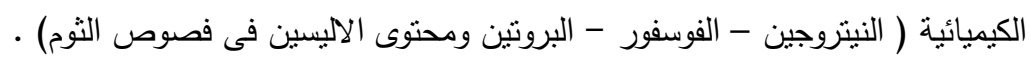

البريد الالكترونى

E-mail:mujareg@gmail.com
موقع المجلة

Mujareg.blogspot.com 
